\title{
Training Needs of Farmers With Respect to New Agricultural Practices
}

\author{
H.C. Chhodavadia ${ }^{1}$, N.S. Joshi ${ }^{2 *}$, V.S. Parmar ${ }^{2}$, M.L. Patel $^{2}$ and P.J. Prajapati ${ }^{2}$ \\ ${ }^{1}$ Directorate of extension education, JAU, Junagadh, India \\ ${ }^{2}$ Krishi Vigyan Kendra, JAU, Amreli, India
}

*Corresponding author

\section{A B S T R A C T}

\section{Keywords \\ Training needs, \\ Pesticides, Fertilizers, \\ Seeds, New agricultural \\ practices \\ Article Info \\ Accepted: \\ 07 October 2018 \\ Available Online: \\ 10 November 2018}

The present study was conducted in Krishi Vigyan Kendras operational area of Amreli district. Out of 11 talukas, 5 talukas selected randomly. Out of 5 selected talukas, 2 villages will be selected from each taluka randomly 5 villages selected. Among selected villages, 10 Farmers from each village were selected for the study. Thus, total 100 respondents were selected for this study. Study revealed that majority of the respondents training needs related to fertilizers is vermi composting and in case of seeds, improved varieties and hybrids of different crops, related to pesticides it was control of disease and insect by proper pesticides and lastly, regarding farm machinery and implements it was getting subsidy and loan.

\section{Introduction}

In Saurashtra region the Amreli is agriculturedominated district. About $80 \%$ of population is engaged in agriculture and allied activities. The Amreli district offers good scope for Agricultural development. Agricultural Production potential depends mostly on the management practices. These practices vary significantly across various agro-ecological regions due to many factors.

Decision making process on farm matter, perform many of the farm operations and undertake many responsibilities concerning management of farm activity. Agricultural activities are the main areas of the economic activities for rural area.
Thus for making training more effective, it should be based on farmers felt needs.

The training programme which is not need based may have a little impact on bring desired change in the clientele system.

Keeping this fact in view, the future study of training needs of farmer with respect to new agricultural production practices in Amreli district of Saurashtra region of Gujarat State will be undertaken with following specific objective.

To study the training needs of the farmers with respect to New Agricultural practices related to fertilizers, seed, pesticide, machinery and implement. 


\section{Materials and Methods}

The study was beining conducted in Krishi Vigyan Kendras operational area of Amreli district. Out of 11 talukas, 5 talukas viz., Amreli, Bagasara, Savarkundla, Rajula and babara selected randomly. Out of 5 selected talukas, 2 villages will be selected from each taluka randomly viz., Champathal, babapur, Mandavda, samadhiyala, gadhakda, likhala, agariya, Katar, Charkha, bambhaniya. Among selected villages, 10 Farmers from each village were selected for the study. Thus, total 100 respondents were selected for this study. The questionnaire was prepared in local language in accordance with the objectives.

Training needs of the farmers were assessed under five sub heads which include training needs related to fertilizers, Seed, Pesticides, farm machinery and implements and animal feed and chemicals. The training needs were assessed by ranking them according to immediate necessities felt by farmer and scoring of 3,2 and 1 was given to the items most needed, somewhat needed and not needed respectively. Firstly, the total training need score of a particular item was calculated considering the responses expressed by all the respondents. Secondly, the mean score of a particular item was worked out by dividing the total score of their particular item with the total number of respondents. Finally, based on the mean score, the rank order of preference for training in a particular area was found out.

\section{Results and Discussion}

Training needs of the farmers with respect to New Agricultural practices

An attempt was made to know the training needs by respondents and frequency and percentage for each training needs were calculated. Then they were ranked and presented in Table 1.
The data presented in Table 1 observed that most important training need of farmers related to fertilizers is vermi composting (2.64) and ranked first which in conformity with Singh et al., (2006) who revealed that majority of the respondents expressed training needs for methods of vermin compost making.

Further, fertigation (2.60) and micro nutrients fertilizers was ranked second by the respondents. Moreover, respondents had given preference to Nutrient contents in fertilizers (2.53), Methods of fertilizer application and Methods of fertilizer application (2.44), Composting (2.42), Methods of nitrogenous fertilizer application (2.40), Soil testing for fertilizer application (2.26), Bio-fertilizers (2.22), Type of fertilizers (2.15), Cake fertilizers (2.12), Implements used for fertilizer application (1.94), Go-down construction (1.88), Fertilizer doses for crops (1.83), Fertilizer store (1.63) which were ranked at III, IV, V, VI, VII,VII, VIII, IX, X, XI, XII, XIII, XIV. This finding are supported with Lego et al., (2018), Bassim, (2016), Waghmode et al., (2014) and Prashanth et al., (2013).

Ranks reflected that respondents interests towards organic farming and efficient use of farm residues so they are very interested towards vermi-composting. Apart from that they have also need interested on fertigation technology and micro nutrients fertilizers In addition, respondents had very much preference to trainings needs regarding nutrient content in fertilizers and INM and methods of fertilizer application showing farmers interest in economic and efficient use of fertilizers. Later on, ranks show respondents may have some knowledge about these aspects and hence score are low.

The data presented in Table 2 indicated that improved varieties and hybrids of different crops (2.63) was given as most pressed areas 
of training need by respondents followed by seed treatment (2.56), type of seeds (2.56), Certified seeds (2.50), Ideal seed storage (2.46), germination power of seeds of different crop (2.45), Fumigation to seeds (2.23), Cultivation of hybrids of different crops (2.16), Viability of seeds of different crops (2.15) and hence ranked II, III, IV, V, VI, VII,VII, VIII and IX respectively. This finding is supported with Lego et al., (2018), Bassim, (2016) and Waghmode et al., (2014).
Ranks showed that respondents are very curious to know about what kinds of variety him or her cultivated, can they used it in next year or not etc. Moreover, need of training about seed treatment indicated that respondents awareness regarding soil borne diseases or may be the area have problem of this kinds of soil borne diseases. It is very interested and good for agricultural point of view that respondent's need of training area were type of seeds and certified seeds also.

Table.1 Training needs of the respondents with respect to New Agricultural

Practices related to Fertilizer

\begin{tabular}{|c|c|c|c|c|c|c|}
\hline Training needs & $\begin{array}{l}\text { Most } \\
\text { Needed }\end{array}$ & $\begin{array}{l}\text { Somewhat } \\
\text { Needed }\end{array}$ & $\begin{array}{l}\text { Not } \\
\text { Needed }\end{array}$ & Total & $\begin{array}{l}\text { Mean } \\
\text { Score }\end{array}$ & Rank \\
\hline Vermin-composting & 70 & 24 & 6 & 100 & 2.64 & I \\
\hline Fertigation & 69 & 22 & 9 & 100 & 2.60 & II \\
\hline Micro-nutrients fertilizers & 63 & 34 & 3 & 100 & 2.60 & II \\
\hline Nutrient contents in fertilizers & 57 & 39 & 4 & 100 & 2.53 & III \\
\hline $\begin{array}{ll}\text { Integrated } & \text { nutrient } \\
\text { management } & \\
\end{array}$ & 56 & 32 & 12 & 100 & 2.44 & IV \\
\hline $\begin{array}{l}\text { Methods of } \\
\text { application }\end{array}$ & 51 & 42 & 7 & 100 & 2.44 & IV \\
\hline Composting & 64 & 14 & 22 & 100 & 2.42 & $\mathrm{~V}$ \\
\hline $\begin{array}{l}\text { Methods of nitrogenous } \\
\text { fertilizer application }\end{array}$ & 49 & 42 & 9 & 100 & 2.40 & VI \\
\hline $\begin{array}{l}\text { Soil testing for fertilizer } \\
\text { application }\end{array}$ & 47 & 32 & 21 & 100 & 2.26 & VII \\
\hline Bio-fertilizers & 32 & 58 & 10 & 100 & 2.22 & VIII \\
\hline Type of fertilizers & 23 & 69 & 8 & 100 & 2.15 & IX \\
\hline Cake fertilizers & 30 & 52 & 18 & 100 & 2.12 & $\mathrm{X}$ \\
\hline $\begin{array}{l}\text { Implements used for fertilizer } \\
\text { application }\end{array}$ & 20 & 54 & 26 & 100 & 1.94 & XI \\
\hline Go-down construction & 23 & 42 & 35 & 100 & 1.88 & XII \\
\hline Fertilizer doses for crops & 31 & 21 & 48 & 100 & 1.83 & XIII \\
\hline Fertilizer store & 16 & 31 & 53 & 100 & 1.63 & XIV \\
\hline
\end{tabular}


Table.2 Training needs of the respondents with respect to New Agricultural Practices Related to Seed

\begin{tabular}{|l|l|l|l|l|l|l|}
\hline Training needs & $\begin{array}{l}\text { Most } \\
\text { Needed }\end{array}$ & $\begin{array}{l}\text { Somewhat } \\
\text { Needed }\end{array}$ & $\begin{array}{l}\text { Not } \\
\text { Needed }\end{array}$ & $\begin{array}{l}\text { Total } \\
\text { Mean } \\
\text { Score }\end{array}$ & Rank \\
\hline $\begin{array}{l}\text { Improved varieties and hybrids of different } \\
\text { crops }\end{array}$ & 72 & 19 & 9 & 100 & $\mathbf{2 . 6 3}$ & I \\
\hline Seed treatment & 70 & 16 & 14 & 100 & $\mathbf{2 . 5 6}$ & II \\
\hline Type of seeds & 65 & 21 & 14 & 100 & $\mathbf{2 . 5 1}$ & III \\
\hline Certified seeds & 64 & 22 & 14 & 100 & 2.50 & IV \\
\hline Ideal seed storage & 56 & 34 & 10 & 100 & 2.46 & V \\
\hline Germination power of seeds of different crop & 58 & 29 & 13 & 100 & 2.45 & VI \\
\hline Fumigation to seeds & 38 & 47 & 15 & 100 & 2.23 & VII \\
\hline Cultivation of hybrids of different crops & 24 & 68 & 8 & 100 & 2.16 & VIII \\
\hline Viability of seeds of different crops & 42 & 31 & 27 & 100 & 2.15 & IX \\
\hline
\end{tabular}

Table.3 Training needs of the respondents with respect to New Agricultural Practices related to pesticides

\begin{tabular}{|l|l|l|l|l|l|l|}
\hline Training needs & $\begin{array}{l}\text { Most } \\
\text { Needed }\end{array}$ & $\begin{array}{l}\text { Somewhat } \\
\text { Needed }\end{array}$ & $\begin{array}{l}\text { Not } \\
\text { Needed }\end{array}$ & Total & Score & Rank \\
\hline $\begin{array}{l}\text { Control of disease and insect by proper } \\
\text { pesticides }\end{array}$ & 76 & 24 & 0 & 100 & $\mathbf{2 . 7 6}$ & I \\
\hline $\begin{array}{l}\text { Type of pesticides } \\
\text { Protection of the stored seeds from pest }\end{array}$ & 72 & 24 & 4 & 100 & $\mathbf{2 . 6 8}$ & II \\
\hline $\begin{array}{l}\text { Preparation of solution of pesticides for } \\
\text { spraying }\end{array}$ & 70 & 24 & 7 & 100 & $\mathbf{2 . 6 2}$ & III \\
\hline $\begin{array}{l}\text { Protective measures and treatment over } \\
\text { poisoning }\end{array}$ & 61 & 27 & 12 & 100 & 2.49 & V \\
\hline $\begin{array}{l}\text { Methods of proper spraying and dusting } \\
\text { Types of improved sprayers and dusters }\end{array}$ & 48 & 31 & 21 & 100 & 2.27 & VI \\
\hline \begin{tabular}{l} 
Disposal of empty bottles and containers \\
\hline
\end{tabular} & 38 & 28 & 26 & 100 & 2.20 & VII \\
\hline
\end{tabular}

Table.4 Training needs of the respondents with respect to New Agricultural practices related to related to machinery and implements

\begin{tabular}{|c|c|c|c|c|c|c|}
\hline & & & & & \multicolumn{2}{|c|}{$\mathrm{n}=100$} \\
\hline Training needs & $\begin{array}{l}\text { Most } \\
\text { Needed }\end{array}$ & $\begin{array}{l}\text { Somewhat } \\
\text { Needed }\end{array}$ & \begin{tabular}{|l|} 
Not \\
Needed
\end{tabular} & Total & $\begin{array}{l}\text { Means } \\
\text { Score }\end{array}$ & Rank \\
\hline Regarding getting subsidy and loan & 72 & 22 & 6 & 100 & 2.66 & I \\
\hline Repairing of machinery and implements & 45 & 32 & 23 & 100 & 2.22 & II \\
\hline Purchasing of machinery and implements & 46 & 29 & 25 & 100 & 221 & III \\
\hline Operating of machinery and implements & 42 & 29 & 29 & 100 & 213 & IV \\
\hline Regarding driving & 7 & 15 & 78 & 100 & 129 & $\mathrm{~V}$ \\
\hline
\end{tabular}


The data presented in Table 3 observed that control of disease and insect by proper pesticides (2.76) was most needful training need and got first ranked followed by Types of pesticides (2.68), Protection of the stored seeds from pest (2.62), Preparation of solution of pesticides for spraying (2.61), Protective measures and treatment over poisoning (2.49), Methods of proper spraying and dusting (2.27), Types of improved sprayers and dusters(2.20), Disposal of empty bottles and containers (2.02) which ranked II, III, IV, V, VI, VII, and VIII respectively. This finding is supported with Lego et al., (2018), Bassim, (2016), Pandey et al., (2015), Punitha, et al., 2012 and Sarda and Gill (2005).

It was much cleared from the ranks that respondent wants to implements proper plant protection measures in their field.

Regarding farm machinery and implements data presented in Table 4 revealed that regarding getting subsidy and loan (2.66) most needed training followed by repairing of machinery and implements (2.22), purchasing of machinery and implements (2.21), operating of machinery and implements (2.13), regarding driving (21.29) which ranked II, III, IV and V respectively. This finding is supported with Waghmode et al., (2014).

In conclusion, training needs of respondents clearly concluded that majority of the respondents training needs related to fertilizers is vermi composting followed by fertigation and micro nutrients fertilizers, nutrient contents in fertilizers, methods of fertilizer application and in case of seeds, improved varieties and hybrids of different crops, seed treatment, type of seeds, certified seeds. Whereas, related to pesticides it was control of disease and insect by proper pesticides, types of pesticides, protection of the stored seeds from pest, preparation of solution of pesticides for spraying and lastly, regarding farm machinery and implements it was getting subsidy and loan, repairing of machinery and implements, purchasing of machinery and implements.

\section{References}

Bassim, K. 2016. Training Needs of Rice Farmers in Mahanawiyah District, ALQadisiya Province, Iraq. Turkish Journal of Agriculture - Food Science and Technology, 4(12): 1072-1076

Inne Lego, R. Bordoloi, Pankaj Kumar Meghwal, Rajkumar Josmee Singh and Ram Singh. 2018. Training Needs Assessment of Agricultural Extension Personnel in Arunachal Pradesh, India. Int.J.Curr.Microbiol.App.Sci. $\quad 7(01)$ : 1684-1694.

Pandey, R. K., Doharey, R.K., Singh, R. K., Mishra, A. K., Pandey, J., Kumar, M. and Dwivedi, A. 2015. A Critical Analysis on Training Needs of Farmers About Mustard Production Technology. International Journal of Agriculture Sciences, 7 (14): 892-895.

Prashanth, P., Jagan Mohan Reddy, M. and Sreenivasa Rao, I. 2013. Training needs of cotton farmers on organic cotton production technologies in Andhra Pradesh. Agriculture Update, 8(1\&2): 14-18.

Punitha, P., Singh, S. B. and Seetharaman, R. N. 2012. Gender differences on training needs among farmers' discussion groups. Indian Research Journal of Extension Education. 12(1):73-77.

Sarda, M. K. and Gill S. S. 2005. Training needs of the input dealers on pesticide application on cotton crop in Punjab. Management Extension Research Review, 6(1): 63-74.

Singh, J., B. Bhimawat S., and Punjabi N. K. 2006. 'Constraints and training needs for adoption of vermiculture technology 
among the farmers of 'Jhadol panchayat samiti in Udaypur district of Rajasthan. Rajasthan Journal Extension Education. 14:124-126.

Waghmode, Y. J., Desai, A. N. and Sawant, agricultural input dealers in transfer of agriculture technology in Ratnagiri district of Konkan region. Agriculture Update, 9(4): 543-546.

\section{How to cite this article:}

Chhodavadia, H.C., N.S. Joshi, V.S. Parmar, M.L. Patel and Prajapati, P.J. 2018. Training Needs of Farmers With Respect to New Agricultural Practices. Int.J.Curr.Microbiol.App.Sci.

7(11): 577-582. doi: https://doi.org/10.20546/ijcmas.2018.711.069 